\section{NRCS Proceeds with Proposal to Restore Prairie}

\author{
By John Pitre, Wildlife Biologist with USDA, \\ NRCS in Louisiana
}

The USDA Natural Resources Conservation Service (NRCS) through its Wetlands Reserve Program (WRP) is proceeding with a proposal to restore approximately 240 acres of Gulf Coastal Prairie near Gueydan, Louisiana.

The project area was in a rice/soybean rotation prior to recently being signed up for consideration under WRP, a program which converts eligible marginal agricultural land back to (as closely as practical) what existed prior to agricultural conversion. The major em-

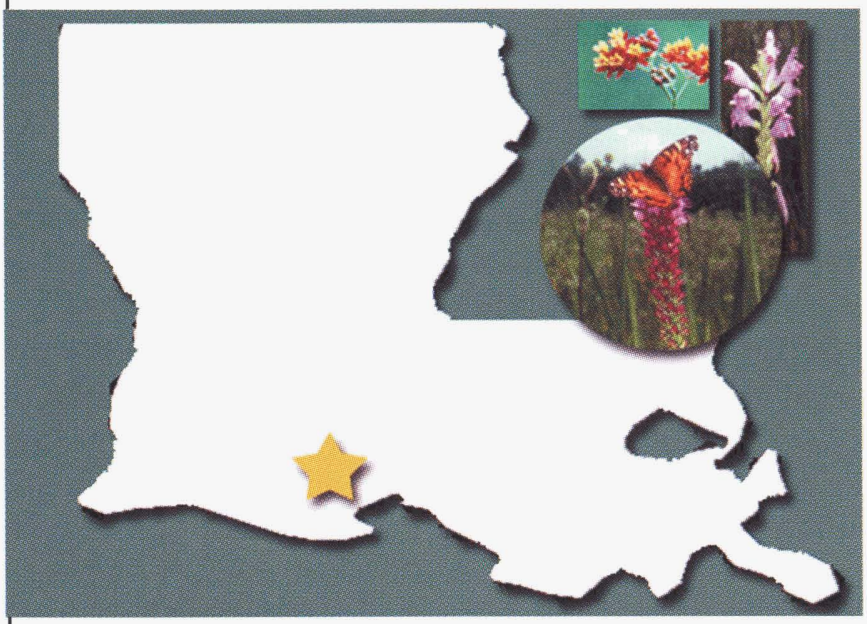

Map locating prairie restoration project within Louisiana.

phasis of WRP is to protect, restore, and enhance the functions and values of wetland ecosystems.

Most WRP sites in Louisiana are found along the floodplain of the major rivers, and consist of bottomland hardwood wetland restoration. This project is quite different. Various native grasses, forbs, and wildflowers will be planted, and controlled fire will be utilized to rejuvenate and maintain the grass-dominated habitat. Without the use of controlled burning, many non-indigenous herbaceous and woody plants would invade the site and make restoration impossible.

Although 240 acres is only a small portion of the 2.5 million acres of "Cajun" Prairie that once existed in Southwest Louisiana, this project has the potential to provide many positive impacts. It will provide the protection and enhancement of open space and the aesthetic quality of Gulf Coastal Prairies. Prairie flowers

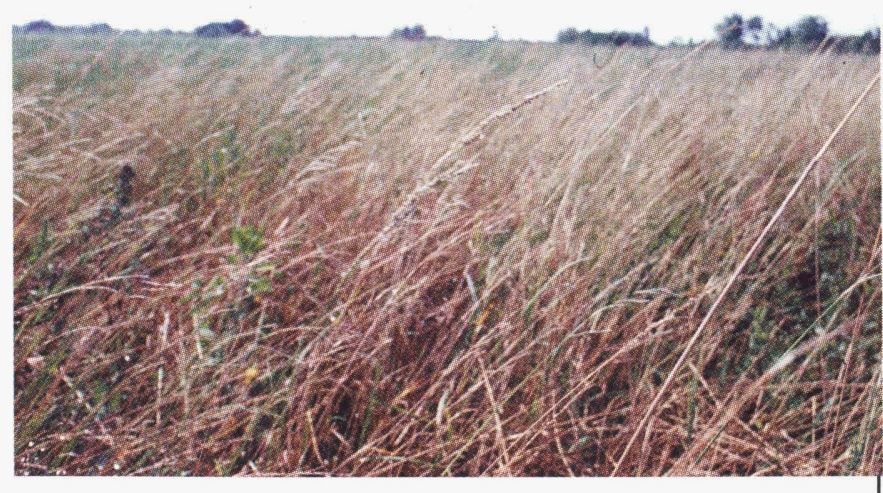

“Cajun" prairie containing several species including brown-seed paspalum (Paspalum plicatulum), switchgrass (Panicum virgatum), maiden-cane (Panicum hemitomon), angelstem beaksedge (Rhynchospora caduca), marshhay cordgrass (Spartina patens), etc.

bloom in a vivid range of colors. Many of these plants were used by Native Louisianians and European settlers for foods, spices, dyes, textiles, and medicines.

As wetlands provide, there will be improvements to surface and groundwater quality. Habitat will be provided for many bird species especially shorebirds, wading birds, waterfowl, raptors, and grassland species like Henslow's sparrow and the loggerhead shrike. Also, many insects including butterflies, like the gulf fritillary, and dragonflies, such as the unique prairie forceptail, and numerous other insects will benefit.

Another positive impact hopefully will be to foster the fact that this unique and vital part of the biosphere has almost vanished.

Serving in an advisory capacity, several partnerships have developed to assist NRCS with this restoration. These include: the Cajun Prairie Habitat Preservation Society, USGS $\mathrm{N}$ a $\mathrm{t}$ i o $\mathrm{n}$ a $\mathrm{l}$
Harvesting local ecotypes of little bluestem (Schizachyrium scoparium) for the prairie restoration project.

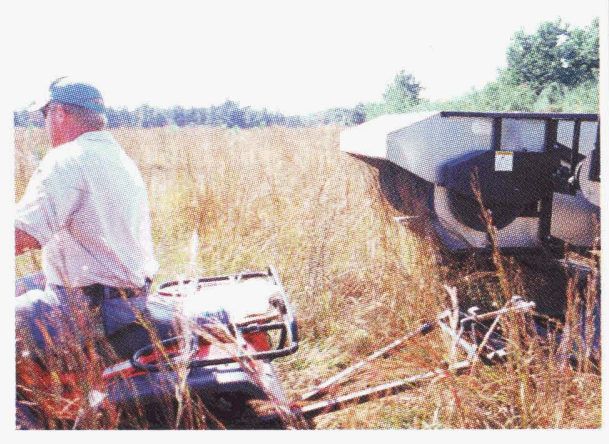

$\mathrm{W}$ e $\mathrm{t} l \mathrm{and} \mathrm{s}$

Research Center, University of Louisiana at Monroe, Louisiana State University at Eunice, The Nature Conservancy, Ducks Unlimited, Inc., Louisiana Department of Wildlife and Fisheries, and USDI Fish and Wildlife Service. 